\title{
Pengaruh Medication Therapy Management (MTM) terhadap Outcome Klinik dan Kualitas Hidup Pasien Hipertensi di Puskesmas Kota Yogyakarta
}

\author{
The Effect of Medication Therapy Management (MTM) on Clinical Outcome and Quality of Life of \\ Hypertension Patients in Puskesmas Kota Yogyakarta
}

\author{
Tiara Dewi Salindri Pratama, Nanang Munif Yasin*, Susi Ari Kristina \\ Fakultas Farmasi, Universitas Gadjah Mada, Yogyakarta \\ Submitted: 25-07-2020 Revised: 01-10-2020 \\ Korespondensi : Nanang Munif Yasin : Email : nanangy@yahoo.com
}

Accepted: $18-12-2020$

\begin{abstract}
ABSTRAK
Medication therapy management (MTM), merupakan model pelayanan yang ditujukan untuk membantu permasalahan kesehatan umum dengan mencegah morbiditas dan mortalitas terkait dengan pengobatan, sehingga kualitas hidup pasien dapat meningkat. Hipertensi adalah salah satu penyakit tidak menular (PTM) yang menjadi masalah serius saat ini yang membutuhkan terapi jangka panjang. Penelitian ini bertujuan untuk mengetahui pengaruh pemberian MTM terhadap outcome klinis dan kualitas hidup pasien kepatuhan pada pasien hipertensi di puskesmas kota Yogyakarta. Jenis penelitian yang digunakan merupakan quasi eksperimental one group with pretest-posttest design. Analisis menggunakan uji paired sample t-test dan Wilcoxon test dengan signifikansi yang digunakan $\mathrm{P}<0,05$. Responden berjumlah 70 orang, sebanyak 67,1\% merupakan perempuan. Karakteristik umur mayoritas 55-64 tahun dengan presentase 51,4\%, tingkat pendidikan mayoritas SMA dengan 42,8\%, pekerjaan non PNS dengan persentase $45,7 \%$, lama terdiagnosa didominasi $1-10$ tahun $(77,1 \%)$ dan penyakit penyerta diabetes melitus paling banyak terjadi $(10,0 \%)$. Hasil penelitian didapatkan kualitas hidup meningkat dari sebelum mendapatkan MTM 54,4 \pm 8,9 dan sesudah intervensi MTM 60,4 $\pm 6,6$ dengan nilai $\mathrm{P}<0,001$. Outcome klinik dari sistolik 159,2 $\pm 8,9 \mathrm{mmHg}$ dan diastolik 103,8 $\pm 8,0 \mathrm{mmHg}$ sebelum MTM menjadi 144,1 $\pm 14,4$ $\mathrm{mmHg}$ untuk sistolik serta $89,7 \pm 8,8 \mathrm{mmHg}$ diastolik dengan nilai $p<0,001(p<0,05)$ untuk tekanan darah sistolik dan nilai p: 0,016 $(p<0,05)$ setelah mendapatkan intervensi MTM. Medication Therapy Management (MTM) memiliki pengaruh yang bermakma terhadap meningkat nya kualitas hidup dan outcome klinis pasien hipertensi. Dapat dilihat semakin tinggi kualitas hidup pasien maka tekanan darah menjadi semakin terkontrol.
\end{abstract}

Kata kunci: hipertensi; kualitas hidup; outcome klinis; Medication therapy management; SF-36

\begin{abstract}
Medication therapy management (MTM), is a service model aimed at helping general health problems by preventing morbidity and mortality. Hypertension is a non-communicable disease which is a serious health problem which requires long-term therapy. This study aims to see the effect of MTM on clinical Outcomes and quality of life of patients in hypertensive patients. This type of research is a quasi experimental one group with a pretest-posttest design. Analysis using paired sample t-test and Wilcoxon test with a significance used $P<0,05$. Respondents were 70 people, 67,1\% were women. The characteristics of the majority age are 55-64 years with a percentage of 51,4\%, the majority of education level is high school with 42,8\%, non-civil servant jobs with a percentage of 45,7\%, the length of diagnosis is dominated by $1-10$ years $(77,1 \%)$ and comorbidities diabetes mellitus occurred the most $(10,0 \%)$. The results showed that the quality of life increased from before getting MTM 54,4 $\pm 8,9$ and after MTM intervention 60,4 \pm 6,6 ( $P$ value $<0,001$ ). Clinical outcome from systolic $159,2 \pm 8,9 \mathrm{mmHg}$ and diastolic $103,8 \pm 8,0 \mathrm{mmHg}$ before MTM to $144,1 \pm 14,4 \mathrm{mmHg}$ for systolic and $89,7 \pm 8,8 \mathrm{mmHg}$ for diastolic with $p$ value $<0,001$ ( $p$ $<0,05)$ for systolic blood pressure and $p$ value: $0,016(p<0,05)$ after receiving MTM intervention. Medication Therapy Management (MTM) has a significant influence on improving the quality of life and clinical Outcomes of hypertensive patients. The higher the quality of life of patients, blood pressure becomes more controlled.
\end{abstract}

Keywords: clinical outcome; hypertension; medication therapy management; quality of life; SF-36

JMPF Vol 10(4), 2020 | DOI : 10.22146/jmpf.58113 


\section{PENDAHULUAN}

Medication therapy management (MTM), merupakan sebuah model pelayanan yang ditujukan untuk membantu permasalahan kesehatan umum dengan mencegah morbiditas dan mortalitas terkait dengan pengobatan, sehingga kualitas hidup pasien dapat meningkat ${ }^{1}$. Pada pasien dengan penyakit kronis seperti hipertensi, pengobatan yang dilakukan berada dalam kurun waktu yang panjang. Adanya praktek MTM ini dapat sebagai evaluasi dan pemastian bahwa pengobatan berjalan optimal dan sesuai dengan kondisi pasien. MTM memiliki tujuan untuk mengoptimalkan hasil terapi yang di berikan kepada pasien. Harapan dari program ini, angka terjadinya risiko efek samping obat, interaksi obat, kejadian polifarmasi dan masalah terkait pengobatan lainnya dapat diminimalisir dengan optimal. Tujuan lainnya untuk menyadarkan pasien mengenai penyakit dan obat yang diterimanya sehingga tingkat pengetahuan, kepatuhan, kualitas hidup, dan hasil akhir terapi dapat diraih pasien dengan se -optimal mungkin².

Perbedaan antara MTM dengan pharmacetical care, pendekatan yang dilakukan Hepler Stran memberikan definisi untuk pharmaceutical care yaitu suatu kefarmasian yang dapat meningkatkan kualitas hidup pasien ${ }^{3}$. Program MTM sendiri dirancang menjadi pelayanan untuk mengoptimasi hasil terapi pada pasien dengan meningkatkan pemahaman pasien terkait penyakit yang dideritanya, obat yang diterima, dengan kolaborasi dari tenaga kesehatan lainnya yang disesuaikan dengan evidence base medicine (EBM) terkait dan kondisi pasien ${ }^{4}$.

Pelaksanaan MTM secara lengkap terdapat 5 tahapan, yaitu Medication therapy review (MTR), bertujuan untuk mendapatkan informasi mengenai pasien, dan menilai ketepatan terapi yang diterima pasien. Personal medication record (PMR), pada tahap ini, pasien akan menerima catatan lengkap obat yang dikonsumsi, berisi informasi untuk membantu pasien dalam menjalankan manajemen terapi keseluruhan yang diterimanya. Medication-related action plan adalah daftar tindakan yang harus dilakukan pasien untuk mengetahui sejauh mana perkembangan menejemen diri dalam terapi obatnya. Interventtion and/or referral adalah tahap dimana apoteker memberikan konsultasi serta adanya intervensi untuk mengatasi masalah terkait pasien, selain itu memberikan rekomendasi rujukan ke dokter atau tenaga kesehatan lainnya jika dirasa perlu dilakukan. Documentation and Follow-up dilakukan untuk untuk mengevaluasi perkembangan pasien ${ }^{3}$.

MTM dirasa penting dalam meningkatkan pengetahuan pasien terhadap obat-obatan yang diterima, dan dapat mendeteksi segala reaksi obat yang merugikan terkait dengan terapi secara cepat. Program MTM memiliki dampak positif yang besar dalam mempengaruhi hasil terapi pasien dan kualitas hidup pasien ${ }^{5}$. Tidak hanya di dunia kefarmasian internasional, dalam dunia kefarmasian nasional pun MTM telah dikenalkan kepada para apoteker. Pada tahun 2018 terdapat kebijakan baru dalam sistem BPJS (Badan Penyelenggara Jaminan Sosial), yaitu untuk pelayanan pasien PRB (Program Rujuk Balik) akan berbasis MTM. PRB adalah program unggulan untuk pasien penyakit kronis. Penyakit kronis yang dimaksud di atas salah satu diantaranya adalah hipertensi. ${ }^{6}$

Hipertensi adalah penyakit yang didefinisikan sebagai adanya peningkatan tekanan darah arteri secara persisten pada seseorang. Penyakit hipertensi merupakan gerbang pembuka seseorang mengalami penyakit kardiovaskular lainnya jika tidak dapat terkontrol dengan baik ${ }^{7}$. Prevalensi seseorang yang mengalami hipertensi meningkat dari tahun ke tahun. Menurut WHO pada tahun 2025, 29\% populasi dunia akan mengalami penyakit hipertensi. Prevalensi Negara berkembang akan jauh lebih tinggi sebesar 40\% dibandingkan dengan Negara maju yang diperkirakan $35 \%{ }^{8}$. Hasil Riskesdas (Riset Kesehatan Dasar) tahun 2018 menunjukan bahwa terjadi peningkatan prevalensi hipertensi dari tahun 2013 sebesar 
8,3\% dari 25,8\% (tahun 2013), menjadi 34,1\%, dan wilayah D.I. Yogyakarta menempati urutan ke-3 kasus hipertensi di Indonesia9,10.

Hipertensi memiliki hubungan dengan rendahnya kualitas hidup, terutama dalam domain fungsi fisik. Penurunan kualitas hidup dapat berimplikasi terhadap pengobatan, outcome klinis, sampai dengan komplikasi yang dapat menimbulkan perburukan kualitas hidup pasien hipertensi. Pasien hipertensi yang tidak terkontrol, akan memiliki faktor resiko lebih besar pada kejadian kardiovaskuler lainnya seperti kejadian stroke, infark miokard, gagal jantung, gagal ginjal, diabetes militus dan atherosclerosis ${ }^{1}$.

Pada kasus hipertensi berat, adanya risiko terjadinya komplikasi sangat tinggi. Komplikasi tersebut dapat memperparah kondisi pasien dan akan menurunkan kualitas hidup pasien ${ }^{11}$. Kualitas hidup yang dimaksud merupakan evaluasi semua aspek kehidupan. Upaya pencegahan komplikasi pada penderita hipertensi dapat dilakukan dengan menjaga angka tekanan darah agar tetap stabil dan mendekati goal terapi yang telah ditentukan ${ }^{12}$. Beberapa faktor utama yang berperan dalam kegagalan pengontrolan tekanan darah adalah rendahnya faktor pengetahuan dan ketidakpatuhan pasien terhadap pengobatan yang diberikan yang berimbas pada perburukan outcome pasien hipertensi ${ }^{13}$.

Berbagai studi menunjukan bahwa adanya perbaikan outcome klinik dapat meningkatkan kualitas hidup dan menurunkan angka terjadinya komplikasi pada penyakit hipertensi ${ }^{11}$. Kualitas hidup juga merupakan indikator penting untuk mengevaluasi hasil pengobatan hipertensi. Beberapa studi menunjukan bahwa pasien hipertensi memiliki kualitas hidup yang lebih rendah dibandingkan dengan orang yang memiliki tekanan darah normal ${ }^{12}$.

Salah satu penelitian dari Wittayanukorn $\mathrm{dkk}^{14}$ mengenai evaluasi MTM terhadap penyakit kardiovaskuler pada 63 pasien. Pada penelitian tersebut dikatakan bahwa penyakit terbesar yang berperan penting dalam memperparah kondisi pasien merupakan hipertensi yang tidak terkontrol. Setelah adanya intervensi MTM dari farmasis, terdapat peningkatan signifikan dalam pengontrolan tekanan darah. Hal ini terjadi karena MTM memiliki pendekatan yang berbeda dengan model pelayanan kefarmasian yang lama². Model MTM mengajak semua tenaga kesehatan untuk berkolaborasi dengan pendekatan yang lebih mudah diterima pasien. Mengedepankan peningkatan pengetahuan pasien terhadap penyakit yang dialami, obat yang diminum, hal apa saja yang harus dilakukan, dan dihindari untuk tercapainya tujuan terapi yang optimal ${ }^{15}$. Pada penelitian disebutkan, persentase awal hanya $55 \%$ pasien yang dapat mencapai goal tekanan darah ideal berubah menjadi $70 \%$ pasien ${ }^{2}$.

Analisis hubungan adanya perbaikan outcome klinik dapat meningkatkan kualitas hidup pasien hipertensi telah dibuktikan pada beberapa literatur. Terkontrolnya tekanan darah pasien terbukti dapat meningkatkan kualitas hidup pasien tersebut secara signifikan dan memperkecil biaya yang dikeluarkan oleh pasien ${ }^{15}$. Berdasarkan latar belakang tersebut, maka penelitian pengaruh medication therapy management (MTM) oleh apoteker terhadap outcome klinik pasien dan kualitas hidup pasien di Puskesmas Kota Yogyakarta perlu dilaksanakan.

\section{METODE}

\section{Rancangan Penelitian}

Jenis penelitian yang digunakan dalam penelitian ini merupakan penelitian dengan rancangan quasi eksperimental one group with pretest-posttest design. Jarak pengukuran pertama dengan kedua dalam mengambil data berselang 30 hari. Hal ini bertujuan untuk melihat ada tidaknya pengaruh intervensi yang diberikan. Pengukuran kualitas hidup diperoleh menggunakan kuesioner SF-36 (Study Short Form-36), data outcome klinis pasien mengambil dari kartu kontrol yang dibawa oleh pasien. Penelitian ini dilaksanakan di Puskesmas Umbulharjo II, Mergangsan, dan Mantrijeron Kota Yogyakarta pada bulan Maret-April 2020. 
Puskesmas pada penelitian ini dipilih berdasarkan kesediaan apoteker yang bertugas di puskesmas tersebut untuk melaksanakan pelayanan berbasis MTM, dan telah menyetujui informed consent dari peneliti. Penelitian ini telah mendapatkan izin dengan No: KE/FK/0710/EC496/EC/2019 dari Komisi Etik Penelitian Kesehatan Fakultas Kedokteran Universitas Gadjah Mada.

\section{Pengumpulan Data}

Pengambilan sampel pada penelitian ini menggunakan metode non-random purposive sampling. Subyek penelitian yang digunakan dalam penelitian ini pasien hipertensi yang memenuhi kriteria inklusi. Populasi target dalam penelitian ini adalah seluruh pasien hipertensi di puskesmas Umbulharjo II, Mergangsan, dan Mantrijeron kota Yogyakarta, sedangkan populasi terjangkau dalam penelitian ini adalah pasien hipertensi di puskesmas Umbulharjo II, Mergangsan, dan Mantrijeron kota Yogyakarta periode Maret - April 2020. Sampel yang dilibatkan merupakan bagian dari populasi terjangkau yang memenuhi kriteria inklusi dan eksklusi penelitian. Total sampel yang diperoleh sebanyak 70 sampel. Kriteria inklusi yang ditetapkan dalam penelitian ini adalah pasien yang didiagnosa hipertensi dengan umur $\geq 18$ tahun, pasien dengan tekanan darah $\geq 140 / 90$ $\mathrm{mmHg}$, pasien melakukan kontrol rutin minimal 1 bulan sekali selama masa penelitian, pasien dengan outcome klinik yang lengkap yaitu tekanan darah sistolik dan diastolik, bersedia ikut serta dalam penelitian dengan menandatangani informed consent sebagai bukti keikutsertaan penelitian. Kriteria eksklusi yang ditetapkan yaitu kondisi umum pasien sangat lemah atau pasien yang tidak kooperatif, pasien dengan kartu kontrol yang kurang lengkap atau tidak sesuai, pasien yang tidak menyelesaikan pengisian kuesioner, pasien kelompok interverensi yang tidak melakukan kontrol rutin pada periode penelitian dilakukan.

\section{Alat ukur}

Alat ukur penelitian yang digunakan dalam penelitian yaitu kartu kontrol pasien hipertensi, dan kuisioner SF-36 (Study Short Form-36) yang tervalidasi. Kartu kontrol merupakan alat ukur yang digunakan untuk melihat identitas, dan tekanan darah pasien. Kartu kontrol berbentuk kotak persegi panjang bewarna kuning yang diberikan puskesmas kepada pasien berisikan nama, alamat, nama puskesmas, tanggal, dan tekanan darah pasien. Alat ukur ini digunakan untuk melihat outcome klinis pada pasien hipertensi sebelum dan sesudah intervensi.

Instrumen SF-36 digunakan untuk melihat kualitas hidup pasien hipertensi. Terdapat 36 pertanyaan dengan 8 domain yang dapat mencangkup ringkasan kualitas hidup pasien dan dengan penilaian 0-100. Hasil didapatkan berdasarkan wawancara pasien. Delapan domain terdiri dari kuisioner SF-36, diantaranya adalah fungsi fisik, fungsi fungsional, peran fisik, emosional, nyeri tubuh, kesehatan umum, vitalitas, dan kesehatan mental. Semakin tinggi nilai SF-36, maka semakin baik kualitas hidup pasien tersebut ${ }^{16}$.

Uji validitas dan reabilitas kuesioner SF36 telah dilakukan oleh beberapa penelitian. Penelitian pertama dilakukan oleh Chua dkk ${ }^{17}$ di Australia dan Rachmawati $\mathrm{dkk}^{16}$ di Indonesia. Hasil validasi menunjukkan bahwa setiap item pertanyaan telah memenuhi syarat validitas konvergen dan diskriminan (koefisien korelasi item $>0,40)^{16}$. Pada kedua uji reabilitas yang dilakukan, menunjukkan nilai Cronbach Alpha untuk item 8 domain adalah $>0,70$. Nilai Cronbach Alpha $>0,70$ maka item tersebut dapat dikatakan reliabel ${ }^{16,17}$.

Kuisioner SF-36 telah diterjemahkan dalam Bahasa Inggris oleh di lembaga pendidikan bahasa Inggris Universitas Gadjah Mada dan dilakukan facevalidity kepada 45 pasien puskesmas. Face validity dilakukan di 3 puskesmas yang akan dilakukan penelitian, dengan masing-masing pengujian dilakukan ke 15 orang responden. Pertanyaan pada face validity terdapat 8 item pertanyaan mengenai gaya bahasa dan ejaan, urutan dan kejelasan pertanyaan, pemahaman responden serta 
waktu yang di butuhkan dalam membaca kuesioner tentang gaya bahasa dan ejaan, urutan dan kejelasan pertanyaan, pemahaman responden serta waktu yang dilihat saat membaca kuisioner. Rata-rata hasil facevalidity $90 \%$, yang berasumsi isi kuesioner dapat dengan mudah di pahami pasien.

\section{Metode Intervensi}

Metode intervensi pelayanan farmasi berbasis MTM yaitu buku pintar dan kendali obat hipertensi sebagai buku dokumentasi pasien, dan buku dokumentasi apoteker sebagai buku dokumentasi apoteker terhadap terapi dan kondisi pasien. Proses pembuatan buku pintar dan kendali obat hipertensi serta buku dokumentasi apoteker dengan mengacu pada form MTM BPJS tahun 2018. Pada penelitian ini terdapat modifikasi dimana dokumentasi riwayat pasien dan terapi yang digunakan disimpan oleh pasien serta apoteker, sedangkan pada MTM BPJS dokumentasi hanya dilakukan oleh apoteker di fasilitas kesehatan.

Buku pintar dan kendali obat ditujukan kepada pasien subyek penelitian yang berisikan dokumentasi identitas pasien, riwayat penyakit dan pengobatan pasien, lembar kontrol penggunaan obat, dan informasi edukasi terkait dengan hipertensi. Buku pintar memiliki tujuan sebagai bentuk dokumentasi perkembangan penyakit pasien dan terapi pasien secara singkat, dimana buku ini juga dapat sebagai wadah edukasi untuk pasien agar pro-aktif dalam pengobatan yang dijalankan.

Pada halaman pertama berisikan identitas pasien meliputi nama, alamat nomer telepon, nama apoteker, nomer telepon apoteker, pola gaya hidup, dan obat yang diberikan pertama kali. Lembar kedua yaitu lembar assessment berisikan keluhan pasien saat ini, keluhan terkait obat,hasil pemeriksaan laboraturium, ada tidaknya riwayat alergi, penyakit komplikasi, dan riwayat penggunaan obat tambahan jika ada. Lembar selanjutnya yaitu lembar pemeriksaan mandiri yang bertujuan mendokumentasikan pengukuran laboraturium yang dilakukan secara mandiri. Lembar selanjutnya pemantauan terapi obat, lembar ini digunakan sebagai kontrol pasien agar tidak lupa untuk meminum obat dengan cara menuliskan obat yang diminum dan mencentang bagian kapan harus minum obat. Lembar terakhir yaitu leaflet mengenai hipertensi. Leaflet ini berisi definisi hipertensi, tanda dan gejala, faktor resiko, apa saja yang harus dilakukan jika terkena hipertensi, pencegahan dan pengendalian hipertensi, pengobatan hipertensi, contoh obat hipertensi, cara minum obat yang benar, cara menyimpan obat, dan motivasi untuk melawan hipertensi bersama.

Buku dokumentasi yang dipegang oleh apoteker berisikan data diri singkat pasien, dan terapi yang diberikan kepada pasien sehingga apoteker dapat melakukan skrining awal ada tidaknya masalah terkait obat kepada setiap pasien. Pada buku dokumentasi berisi nomor pasien, nama, nomor rekam medis, nomot telepon, pengobatan pasien secara keseluruhan (nama obat, dosis, tanggal periksa dan jumlah obat). Pada kolom lainnya terdapat assessment masalah yang mungkin terjadi dari kondisi dan pengobatan yang dilakukan meliputi tanggal, jika ada permasalahan terkait obat, intervensi yang dilakukan untuk menyelesaikan masalah tersebut, dan paraf apoteker yang memberikan assessment.

\section{Jalannya Penelitian Tahap Persiapan}

Pada tahap ini, pengurusan ethical clearance di fakultas kedokteran Universitas Gadjah Mada dilakukan. Pengurusan izin ke Dinas Kesehatan Kota Yogyakarta dan puskesmas Kota Yogyakarta untuk melakukan penelitian juga dilakukan. Tahap terakhir pada tahap persiapan adalah melakukan studi pendahuluan untuk mengetahui populasi penyakit hipertensi di puskesmas kota Yogyakarta.

\section{Tahap Penelitian dan Pengolahan Data}

Peneliti melakukan studi pendahuluan guna menentukan puskesmas yang akan dijadikan lokasi penelitian berdasarkan pada prevalensi penyakit hipertensi yang ada di puskesmas tersebut, dan kesediaan apoteker 
terlibat dalam penelitian MTM. Dari puskesmas yang dipilih tersebut didapatkan Puskesmas Umbulharjo II, Mergangsan, dan Mantrijeron Kota Yogyakarta. Puskesmas yang terpilih, tersebut diberikan pelatihan mengenai pelayanan MTM untuk menyamakan persepsi dengan dilakukannya Focus Group Discussion (FGD).

Pelaksanaan Pretest dilakukan pada bulan Maret 2020 dengan kuesioner SF-36 dan melihat outcome klinis pasien pada kartu kontrol yang pasien pegang. Pelayanan selanjutnya yang dilakukan adalah assessment, konseling, edukasi dari apoteker kepada pasien. Assessment adalah pengumpulan informasi terkait pengobatan pasien dan hal hal yang mempengaruhi pengobatan pasien. Hal ini dimulai dari dilakukannya pengumpulan informasi terkait identitas pasien, riwayat penyakit pasien, Riwayat penggunaan obat, dan kondisi pasien. Data tersebut kemudian dididokumentasikan pada buku pintar yang akan pasien bawa. Pada tahap ini menyangkut dua elemen dari MTM yaitu Medication Therapy Review dan Elemen Personal Medication Record.

Tahap selanjutnya dilakukan konseling dan edukasi oleh apoteker pada penyerahan obat. Hal ini bertujuan untuk mengenalkan pasien terhadap penyakit dan pengobatan yang dijalani dan menggali ada tidaknya masalah terkait dengan obat, dan pemberian solusi terkait dengan masalah penggunaan obat. Konseling pada MTM, tahap ini masuk dalam elemen intervention. Edukasi dilakukan dengan menyelipkan leaflet mengenai pengetahuan seputar hipertensi pada buku pintar yang masuk dalam elemen Medication Related Action Plan. Selanjutnya dilakukan Tindakan follow-up yang pada MTM masuk dalam elemen follow-up.

Follow up dilakukan pada bulan selanjutnya saat pasien melakukan kontrol rutin selanjutnya dengan membawa buku pintar. Pada buku pintar terdapat lembar pemantauan terapi obat yang bertujuan untuk membantu pasien patuh minum obat. Buku pintar juga memfasilitasi kolom dimana pasien dapat menuliskan pengukuran hasil lab yang dilakukan secara mandiri agar dapat dengan mudah melihat perkembangan kondisi pasien. Berbeda dengan buku pintar pasien, buku dokumentasi yang dipegang oleh apoteker berisikan data diri singkat pasien, dan terapi yang diberikan kepada pasien sehingga apoteker dapat melakukan skrining awal ada tidaknya masalah terkait obat kepada setiap pasien. Pengambilan data dilakukan 2 kali yaitu sebelum dilakukan MTM dan pada kontrol selanjutnya, 1 bulan sesudah dilaksanakan MTM kepada pasien. Penelitian hanya dilakukan daam kurun waktu 1 bulan dikarenakan keterbatasan waktu penelitian, akan tetapi pelayanan berbasis MTM dapat diterapkan setelah penelitian ini berakhir.

\section{Tahap Penyusunan Penelitian}

Pada tahap ini, akan dilakukan analisis data terkait penelitian, dan melakukan penulisan hasil yang didapat. Data yang akan dianalisis meliputi sosiodemografi, skor dari kuesioner SF-36, outcome klinis pasien dan ada tidaknya hubungan antar variabel. Hasil akhir analisis data adalah pembahasan dan penarikan kesimpulan penelitian.

\section{Analisis Hasil Penelitian}

Langkah awal dilakukannya analisis data dengan memindahkan data karakteristik pasien, skor SF -36, dan hasil outcome klinis pasien ke dalam worksheet Excel ${ }^{\circledR}$ kemudian dilanjutkan analisa mengunakan software SPSS. Analisis data yang dilakukan menggunakan analisis univariat dan bivariat. Analisis secara deskriptif untuk menggambarkan karakteristik variabel seperti usia, jenis kelamin, tingkat pendidikan, pekerjaan dan penyakit penyerta menggunakan analisis univariat. Uji normalitas pada penelitian ini menggunakan uji normalitas Kolmogorov-Smirnov untuk melihat data penelitian terdistribusi normal atau tidak. Analisis bivariat bertujuan untuk melihat ada tidaknya pengaruh variabel terhadap outcome dan kualitas hidup pasien hipertensi. Uji statistik yang digunakan adalah uji-t tidak berpasangan untuk melihat 
Tiara Dewi Salindri Pratama, et al

Tabel I. Distribusi Karakteristik Responden

\begin{tabular}{llcc}
\hline \multicolumn{1}{c}{ Karakteristik } & Frekuensi & Persentase (\%) \\
\hline Jenis Kelamin & Laki-laki & 23 & 32,9 \\
\multirow{4}{*}{ Usia } & Perempuan & 47 & 67,1 \\
& $\leq 45$ tahun & 4 & 5,7 \\
& $45-54$ tahun & 15 & 21,4 \\
& 55- 64 tahun & 35 & 50 \\
\multirow{5}{*}{ Tingkat Pendidikan } & 65-74 tahun & 14 & 20 \\
& $\geq 75$ tahun & 2 & 2,9 \\
& SD & 11 & 15,7 \\
& SMP & 5 & 7,1 \\
Pekerjaan & SMA & 31 & 44,3 \\
& Universitas & 23 & 32,9 \\
& PNS & 12 & 17,1 \\
Lama Terdiagnosa & Non PNS & 32 & 45,7 \\
& Tidak Bekerja & 26 & 37,1 \\
& $<1$ tahun & 12 & 17,1 \\
& $1-10$ tahun & 54 & 77,1 \\
Penyakit penyerta & 3 & 4,3 \\
& 11-19 tahun & 1 & 1,4 \\
& $\geq 20$ tahun & 7 & 10,0 \\
& Diabetes melitus & 5 & 7,1 \\
& Hiperlipidemia & 2 & 2,9 \\
& DM + Hiperlipidemia & 56 & 80 \\
\hline \multirow{5}{*}{ Tanpa Penyakit penyerta } & &
\end{tabular}

kebermaknaan nilai SF-36 antar kelompok. Analisis menggunakan uji paired sample t-test atau Wilcoxon test (melihat normalitas data) dengan signifikansi yang digunakan $\mathrm{P}<0,05$.

\section{HASIL DAN PEMBAHASAN Karakteristik Responden}

Pada penelitian ini didapatkan 81 populasi terjangkau pasien hipertensi. Sampel yang memenuhi kriteria inklusi berjumlah 70 pasien hipertensi. Berdasarkan data yang diperoleh, data kemudian dikelompokan berdasarkan usia, jenis kelamin, tingkat pendidikan, pekerjaan, lama menderita, dan penyakit penyakit penyerta lainnya untuk mengetahui distribusi pasien depresi. Karakteristik pasien tersebut disajikan pada tabel I.

Dari tabel I diketahui bahwa mayoritas subyek pada penelitian ini berjenis kelamin perempuan, usia pasien didominasi pasien dengan rentang usia 55- 64 tahun. Berdasarkan jenjang pendidikan, mayoritas pasien berpendidikan sedang (SMA), dari segi pekerjaan mayoritas merupakan non PNS seperti wiraswasta, swasta, Buruh. Pasien telah terkena hipertensi paling banyak pada rentang waktu 1-10 tahun, dengan obat yang paling banyak digunakan adalah amlodipin 5 $\mathrm{mg}$, jumlah obat yang dikonsumsi berjumlah 1 obat, dengan terapi yang sama dengan terapi yang sebelumnya telah didapatkan. Penyakit penyerta paling umum ditemukan adalah diabetes melitus yang disusul oleh hiperlipidemia.

Dapat dilihat pada jenis kelamin didominasi oleh perempuan 47 pasien $(67,1)$, disusul laki laki dengan 23 pasien (32,9\%). Hal ini dapat dikarenakan perempuan usia lebih dari 45 tahun biasanya telah mengalami menopause. Perempuan pada masa menopause akan terjadi penurunan sekresi hormon estrogen, dimana hormone estrogen melalui sistem renin angiotensin aldosteron dapat mempengaruhi tekanan darah ${ }^{18}$. Mekanisme kerja hormon estrogen, akan 
menghambat kerja dari enzim renin sehingga pembentukan angiotensin I terhambat, mekanisme kerja lainnya hormone estrogen akan menghambat angiotensin converting enzymes sehingga terjadi penghambatan perubahan angiotensin I menjadi angiotensin II, dan menghalangi angiotensin II untuk berpasangan dengan reseptor angiotensin II. Ketiga mekanisme kerja tersebut yang dapat membantu menurunkan tekanan darah oleh hormone estrogen. Pada masa menopause, akan terjadi perubahan kadar hormone estrogen dalam tubuh. Konsentrasi hormon akan berkurang secara drastis sehingga efek penurunan tekanan darah juga tidak optimal. Sebab inilah alasan pada masa menopause tekanan darah perempuan akan lebih tinggi dibanding laki-laki pada usia yang sama ${ }^{19}$.

Usia mayoritas pasien hipertensi yang menjadi sampel adalah pasien dengan rentang usia lebih dari 55-64 tahun dengan 35 sampel (51,4\%). Pada rentang usia 45-54 tahun terdapat 15 pasien $(21,4 \%)$, rentang $65-74$ tahun 14 pasien $(20 \%), \leq 45$ tahun 4 pasien $(5,7 \%)$, dan $\geq 75$ tahun dengan 2 pasien (2,9\%). Menurut Yoon $\mathrm{dkk}^{20}$, terjadinya hipertensi dapat meningkat seiring dengan peningkatan usia $^{20}$. Hal ini terjadi karena adanya peningkatan sensitivitas natrium dan peningkatan kekakuan pembuluh darah karena terdapat penurunan fungsi tubuh ${ }^{21}$. Peningkatan sensitivitas natrium disebabkan tubuh melakukan kompensasi homeostasis sehingga kebutuhan natrium ditingkatkan. Penurunan elastisitas pembuluh darah dapat menyebabkan terjadinya aterosklerosis dimana terjadi sumbatan yang menghambat aliran darah sehingga terjadi kompensasi berupa pada peningkatan tekanan darah ${ }^{20}$.

Pada tingkat pendidikan, mayoritas pasien hipertensi didominasi oleh lulusan SMA $(42,8 \%)$ kemudian Universitas (32,9\%), SD $(15,7 \%)$, dan SMP (7,1\%)Pendidikan menjadi salah satu faktor tingginya hipertensi berkaitan dengan kurangnya kesadaran akan Kesehatan dikarenakan akses memperoleh pengetahuan informasi kesehatan terbatas, dan terbatasnya fasilitas untuk melakukan periksa mandiri. Pasien dengan tingkat pendidikan rendah akan lebih jarang melakukan pemeriksaan kondisi kesehatannya $^{22}$. Hal ini berkaitan dengan variabel lain yaitu pekerjaan, pada penelitian ini didapatkan pasien dengan pekerjaan swasta atau non PNS (Pegawai Negeri Sipil) sebesar $45,7 \%$, sedangkan pasien tidak bekerja sebanyak $37,1 \%$ dan pasien PNS sebesar $17,1 \%$. Jenis pekerjaan berpengaruh dengan aktivitas fisik yang dilakukan. Aktivitas fisik sangat berpengaruh pada tekanan darah. Pada orang yang bekerja dengan melibatkan aktivitas fisik, lebih dapat terlindungi dari penyakit hipertensi dibandingkan dengan pekerja kantoran. Pekerja kantoran biasanya lebih mengandalkan bantuan mesin otomatis dan duduk lebih dari 6 jam dalam sehari, sehingga aktivitas fisik sangat terbatas. Pada variabel ini yang bermain adalah faktor gaya hidup dan pola makan yang kurang baik serta menunjang terjadinya hipertensi ${ }^{23}$.

Variabel lama penyakit paling banyak didominasi dalam rentang 1-10 tahun dengan $77,1 \%$. Disebutkan bahwa pasien hipertensi memiliki karakteristik terbanyak dengan lama penyakit rata-rata 5 tahun. Semakin lama penyakit maka tingkat kepatuhan akan semakin tinggi ${ }^{23}$.

Pada variabel penyakit penyerta diketahui tidak banyak penyakit penyerta yang terlibat dibuktikan pasien hipertensi tanpa penyakit penyerta sebesar $80 \%$. Penyakit lain yang mendominasi adalah diabetes mellitus (DM) dengan 10,0\%, hiperlipidemia dengan 7,1\%, dan kombinasi diabetes melitus dan hiperlipidemia dengan $2,9 \%$. Penyakit lain yang mendominasi adalah diabetes melitus dengan 10,0\%. Hipertensi dan diabetes banyak dikaitkan satu sama lain. Faktor risiko utama penyakit kardiovaskuler adalah penyakit diabetes melitus (DM) dengan mortalitas kardiovaskuler dua sampai tiga kali lebih tinggi dibanding pasien tanpa $\mathrm{DM}^{24}$. Hiperinsulinemia dan insulin eksogen secara teoritis dapat menyebabkan hipertensi melalui mekanisme vasokonstriksi dan retensi cairan natrium dan cairan dalam tubuh $^{25}$. Aterosklerosis memainkan peran 
Tiara Dewi Salindri Pratama, et al

Tabel II. Skor Kualitas Hidup Total Menggunakan Short Form - 36

\begin{tabular}{cccccc}
\hline Keterangan & $\begin{array}{c}\text { Pretest } \\
\text { Mean } \pm \text { SD }\end{array}$ & $\begin{array}{c}\text { Post-test } \\
\text { Mean } \pm \text { SD }\end{array}$ & Selisih & Nilai P & Keterangan \\
\hline SF36 & $54,44 \pm 8,91$ & $60,40 \pm 6,66$ & 5,96 & 0,000 & Paired Sampel Test \\
\hline
\end{tabular}

Tabel III. Skor Kualitas Hidup Setiap Domain Menggunakan Short Form - 36

\begin{tabular}{cccccc}
\hline Keterangan & $\begin{array}{c}\text { Pretest } \\
\text { Mean } \pm \text { SD }\end{array}$ & $\begin{array}{c}\text { Posttest } \\
\text { Mean } \pm \text { SD }\end{array}$ & Selisih & Nilai P & Keterangan \\
\hline Fungsi Fisik & $76,71 \pm 16,91$ & $81,29 \pm 15,85$ & 4,58 & 0,000 & Wilcoxon Test \\
Peran Fisik & $51,07 \pm 27,72$ & $73,21 \pm 23,04$ & 22,14 & 0,000 & Wilcoxon Test \\
Peran Emosi & $63,32 \pm 29,57$ & $82,85 \pm 21,79$ & 19,53 & 0,000 & Wilcoxon Test \\
Energi & $42,93 \pm 8,66$ & $49,64 \pm 8,52$ & 6,71 & 0,000 & Wilcoxon Test \\
Kesehatan Mental & $54,43 \pm 8,91$ & $60,40 \pm 6,66$ & 5,97 & 0,000 & Paired Sampel Test \\
Fungsi Sosial & $46,42 \pm 16,36$ & $49,10 \pm 15,82$ & 2,68 & 0,014 & Wilcoxon Test \\
Nyeri & $94,89 \pm 13,86$ & $97,46 \pm 7,89$ & 2,57 & 0,005 & Wilcoxon Test \\
Kesehatan Umum & $46,07 \pm 8,33$ & $52,86 \pm 7,15$ & 6,79 & 0,000 & Wilcoxon Test \\
\hline
\end{tabular}

dalam kejadian hipertensi. Mekanisme yang terjadi adalah lipoprotein pasien DM akan mengalami glikosiliasi (lipoprotein terglikosiliasi) yang bersifat sitotoksik terhadap endotel yang menyebabkan terjadinya oksidasi, sehingga terjadi peningkatan lipoprotein peroksida di ruang interstisial dan terjadi akumulasi lemak. Adanya akumulasi lemak menyebabkan terhambatnya katabolisme LDL sehingga LDL mengalami karbamalasi ${ }^{26}$. Ketiga proses tersebut akan menghambat ambilan LDL oleh scavenger cells dalam tubuh baik glikosilasi, oksidasi, dan karbamalasi. Selain LDL, Very Low Density Lipoprotein (VLDL) ikut berperan dengan mengangkut lipid dari hepar ke dinding arteri dalam proses aterogenesis. Adanya sumbatan aterosklerosis ini yang penyebab terjadinya peningkatan systemic vascular resistance yang berhubungan dengan kejadian hipertensi ${ }^{27}$.

\section{Pengaruh MTM terhadap kualitas hidup pasien hipertensi}

Kualitas hidup pada penelitian ini diukur dengan menggunakan SF-36. Tujuan penggunaan kuesioner ini untuk melihat kajian kesehatan yang telah diterapkan pada beberapa penelitian. Kuesioner SF 36 terdiri dari 36 pertanyaan, dan delapan domain kesehatan yakni: (1) Fungsi Fisik, (2) Peran fisik, (3) Nyeri, (4) Kesehatan Umum, (5) Energi, (6) Fungsi Sosial, (7) Peran Emosi (8) Kesehatan Mental. Dari hasil uji normalitas data maka data yang terdistribusi normal akan diuji menggunakan uji parametrik dan untuk data yang tidak normal akan diuji menggunakan uji non- parametrik Wilcoxon Signed Ranks Test. Berikut merupakan hasil analisis yang dilakukan terhadap kualitas hidup dapat dilihat pada tabel II dan III.

Hasil uji statistik skor kualitas hidup SF 36 baik secara total maupun dilakukan setiap domain menunjukan ada perbedaan bermakna pada data sebelum dilakukan MTM dengan setelah dilakukan MTM $(\mathrm{P}<0,05)$. Pada analisis kuesioner SF 36 didapatkan bahwa hasil posttest $(60,40 \pm 6,66)$ memiliki nilai yang lebih besar dari hasil nilai pretest $(54,44 \pm 8,91)$. Hal ini sesuai dengan penelitian dari Wittayanukorn $\mathrm{dkk}^{14}$ mengenai evaluasi MTM terhadap penyakit kardiovaskuler. Pada penelitian tersebut dikatakan bahwa penyakit terbesar yang berperan penting dalam memperparah kondisi pasien merupakan hipertensi yang tidak terkontrol yang menyebabkan penurunan kualitas hidup seseorang. Setelah adanya interferensi MTM dari farmasis, terdapat peningkatan signifikan dalam peningkatan kualitas hidup pasien 
Tabel IV. Pengaruh variabel terhadap kualitas hidup pasien hipertensi setelah diberikan MTM

\begin{tabular}{cccc}
\hline \multicolumn{2}{c}{ Karakteristik } & $\begin{array}{c}\text { Selisih skor SF36 } \\
\text { (Rata-rata } \pm \text { SD) }\end{array}$ & $\begin{array}{c}\text { Nilai p } \\
\text { (Keterangan) }\end{array}$ \\
\hline Jenis Kelamin & Laki-laki & $8,97 \pm 1,2$ & $0,557^{\mathrm{a}}$ \\
Usia & Perempuan & $8,81 \pm 0,86$ & $0,000^{\mathrm{b}}$ \\
& $\leq 45$ tahun & $3,48 \pm 0,49$ & \\
& $45-54$ tahun & $7,90 \pm 0,94$ & \\
Pendidikan & $55-64$ tahun & $8,28 \pm 27,92$ & $0,581^{\mathrm{b}}$ \\
terakhir & 65-74 tahun & $11,86 \pm 1,37$ & \\
& $\geq 75$ & $16,14 \pm 1,25$ & \\
Pekerjaan & SD & $9,12 \pm 1,28$ & $0,336^{\mathrm{b}}$ \\
& SMP & $12,29 \pm 2,11$ & \\
& SMA & $7,26 \pm 0,99$ & $0,824^{\mathrm{b}}$ \\
Lama & Universitas & $10,16 \pm 1,39$ & \\
Terdiagnosa & PNS & $8,96 \pm 1,8$ & \\
& Non PNS & $7,37 \pm 0,9$ & $0,803^{\mathrm{b}}$ \\
& Tidak Bekerja & $10,65 \pm 1,15$ & \\
Penyakit penyerta & $<1$ tahun & $10,48 \pm 2,06$ & \\
& $1-10$ tahun & $8,35 \pm 0,73$ & \\
& 11-19 tahun & $8,95 \pm 4,21$ & \\
& Diabetes melitus & $8,1 \pm 0,5$ & \\
& Hiperlipidemia & $11,60 \pm 4,00$ & \\
& DM + & $8,28 \pm 2,8$ & \\
\hline
\end{tabular}

Keterangan : ${ }^{\mathrm{a}}=$ analisis dengan Mann Whitney; banalisis dengan Kruskal Walis Test

tersebut ${ }^{14}$. Adanya edukasi dan konseling memiliki efek dapat meningkatkan tingkat pengetahuan pasien, kepatuhan pasien dalam penggunaan obat dan pengetahuan penyakit yang dideritanya, hal inilah yang dapat meningkatkan kualitas hidup pasien².

Pada kualitas hidup yang buruk sangat berpengaruh dalam perawatan pasien kronis seperti hipertensi. Pasien yang mengalami hipertensi akan mengalami penurunan kualitas hidup yang signifikan pada semua domain dibanding dengan pasien dengan tensi normal. Skor kualitas hidup yang paling rendah terutama domain emosional, aspek fisik, vitalitas, dan kesehatan mental ditujukan pada pasien hipertensi dengan adanya kerusakan organ target dan pasien dengan komplikasi ${ }^{15}$. Perburukan dan perbaikan kualitas hidup ditunjang oleh banyak faktor. Berikut merupakan variabel yang data mempengaruhi kualitas hidup, disajikan dalam tabel IV.

Pada tabel IV, diketahui bahwa dari ke 6 karakteristik hanya 1 yang paling berpengaruh terhadap kualitas hidup yaitu karakteristik usia dengan $\mathrm{p}<0,001(\mathrm{p}<0,05)$. Pada ke 5 karakteristik tidak terlihat ada pengaruh lain terhadap kualitas hidup. Hal ini terlihat dari nilai $\mathrm{P}>0,05$. Dapat disimpulkan bahwa usia yang memiliki pengaruh terdapat peningkatan kualitas hidup setelah dilakukannya intervensi pelayanan farmasi berbasis medication therapy management (MTM). Sehingga, adanya peningkatan kualitas hidup tidak murni akibat dari intervensi pelayanan farmasi berbasis 
Tabel V. Rata-rata tekanan darah pada pasien hipertensi

\begin{tabular}{cccccc}
\hline \multirow{2}{*}{ Keterangan } & $\begin{array}{c}\text { Pretest } \\
\text { Mean } \pm \text { SD }\end{array}$ & $\begin{array}{c}\text { Post-test } \\
\text { Mean } \pm \text { SD }\end{array}$ & Selisih & $\begin{array}{c}\text { Nilai } \\
\mathbf{P}\end{array}$ & Keterangan \\
\hline Sistolik & $159,20 \pm 17,39$ & $144,17 \pm 14,49$ & 15,03 & 0,000 & Wilcoxon Test \\
Diastolik & $103,83 \pm 8,08$ & $89,70 \pm 8,81$ & 14,13 & 0,016 & Paired Sampel Test \\
\hline
\end{tabular}

medication therapy management (MTM), tetapi dapat dipengaruhi juga oleh adanya faktor usia.

Pada penelitian Xiao $\mathrm{dkk}^{28}$ menyebutkan bahwa pada pasien dengan usia lanjut akan memiliki kualitas hidup yang jauh lebih buruk dibandingkan dengan pasien hipertensi usia produktif. Hal ini dikarenakan organ fungsi pada pasien lansia sudah banyak mengalami penurunan. Selama proses penuaan, terdapat bahaya kesehatan diakibatkan dari perubahan fisiologis dan fungsional, membuat individu lansia lebih rentan terhadap penyakit kronis $^{28}$. Hal tersebut diperberat dengan perkembangan usia semakin banyak tingkat stressor dan permasalahan yang dihadapi dapat mempengaruhi kualitas hidup seseorang. Kualitas hidup yang menurun akan lebih banyak terkait pada domain peran fisik, kesehatan fisik, kesehatan mental, nyeri, dan emosi pasien ${ }^{29}$.

\section{Pengaruh MTM terhadap Outcome klinis pasien hipertensi}

Tujuan penelitian ini adalah ingin mengetahui pengaruh pemberian pelayanan MTM apoteker apakah dapat mempengaruhi tekanan darah pasien hipertensi atau tidak. Data tekanan darah didapat dari kartu kontrol yang dibawa oleh pasien dari setiap puskesmas. Tekanan darah oleh Joint National Committee (JNC) VIII diklasifikasikan menjadi tekanan darah normal, prehipertensi, hipertensi tingkat I dan hipertensi tingkat II. Pada penelitian ini diambil data tekanan darah sistolik dan diastolik masing masing pasien hipertensi ${ }^{30}$. Rata-rata tekanan darah penelitian dapat dilihat pada tabel V.

Dari data tabel $\mathrm{V}$ diketahui bahwa tekanan darah sistolik sebelum adanya interferensi MTM adalah 159,2 mmHg dengan tekanan darah diastolik 103,8 mmHg. Setelah dilakukan MTM dalam kurun waktu 30 hari terdapat penurunan tekanan darah secara umum. Pada tekanan darah sistolik menurun menjadi $144,1 \mathrm{mmHg}$ dengan diastolik 87,7 mmHg. Pada penelitian ini didapatkan pasien mengalami perbaikan dalam penurunan tekanan darah walaupun belum sesuai target. Penurunan tekanan darah dari nilai tekanan darah sebelumnya menunjukan suatu perbaikan kondisi, akan tetapi penurunan tekanan darah tidak selalu dibarengi dengan tercapainya target tekanan darah sesuai dengan pedoman pada satu periode. Pada penelitian Ninh $\mathrm{dkk}^{12}$ mengatakan bahwa pencapaian tekanan darah sesuai dengan target teoritis di Negara berkembang seperti Vietnam, memiliki faktor penghalang yang beragam sehingga sulit dicapai dengan kecenderungan nilai tekanan darah yang buruk. Dalam penurunan tekanan darah sesuai target memerlukan bantuan dari banyak pihak, tenaga kesehatan, keluarga pasien, dan pasien itu sendiri. Garis besar solusi yang dapat diambil adalah menjaga nilai tekanan darah agar terus membaik, dan stabil. Nilai tekanan darah diusahakan agar mendekati target terapi sehingga dapat memperkecil peluang terjadinya komplikasi akibat tidak terkontrolnya tekanan darah ${ }^{12}$.

Intervensi apoteker berupa MTM memberikan dampak positif signifikan terhadap penurunan tekanan darah pasien hipertensi yang diketahui dari nilai $\mathrm{P}<0,05$ yaitu $\mathrm{P}<0,001$ untuk sistolik, dan $\mathrm{p}$ 0,016 diastolik. Hal ini sesuai penelitian Wittayanukorn $\mathrm{dkk}^{14}$ mengenai evaluasi MTM terhadap penyakit kardiovaskuler pada 63 pasien pada tahun 2013 yang menyebutkan bahwa setelah intervensi MTM dari apoteker, 
Tabel VI. Pengaruh variabel terhadap Tekanan Darah Sistolik pasien hipertensi setelah diberikan MTM

\begin{tabular}{|c|c|c|c|}
\hline \multicolumn{2}{|c|}{ Karakteristik } & \multirow{2}{*}{$\begin{array}{c}\begin{array}{c}\text { Selisih skor Sistolik } \\
\text { (Rata-rata } \pm \text { SD) }\end{array} \\
14 \pm 2,77\end{array}$} & \multirow{2}{*}{$\begin{array}{c}\begin{array}{c}\text { Nilai } \mathbf{p} \\
\text { (Keterangan) }\end{array} \\
0,051^{\mathrm{a}}\end{array}$} \\
\hline Jenis Kelamin & Laki-laki & & \\
\hline \multirow{6}{*}{ Usia } & Perempuan & $15,53 \pm 1,89$ & \\
\hline & $\leq 45$ tahun & $10,25 \pm 6,63$ & $0,383^{b}$ \\
\hline & $45-54$ tahun & $13,20 \pm 3,58$ & \\
\hline & 55- 64 tahun & $17,49 \pm 1,97$ & \\
\hline & 65-74 tahun & $11,64 \pm 4,19$ & \\
\hline & $\geq 75$ & $19,0 \pm 5$ & \\
\hline \multirow{4}{*}{$\begin{array}{l}\text { Pendidikan } \\
\text { terakhir }\end{array}$} & SD & $17,27 \pm 4,65$ & $0,741^{\mathrm{b}}$ \\
\hline & SMP & $7,20 \pm 5,26$ & \\
\hline & SMA & $16,9 \pm 2,3$ & \\
\hline & Universitas & $13,13 \pm 2,52$ & \\
\hline \multirow[t]{3}{*}{ Pekerjaan } & PNS & $9,42 \pm 3,54$ & $0,106^{b}$ \\
\hline & Non PNS & $17,16 \pm 1,84$ & \\
\hline & Tidak Bekerja & $15,00 \pm 3,06$ & \\
\hline Lama & $<1$ tahun & $18,42 \pm 3,66$ & $0,165^{b}$ \\
\hline \multirow[t]{3}{*}{ Terdiagnosa } & $1-10$ tahun & $14,48 \pm 1,83$ & \\
\hline & 11-19 tahun & $14,33 \pm 1,33$ & \\
\hline & $\geq 20$ tahun & $15,21 \pm 2,01$ & \\
\hline \multirow[t]{3}{*}{ Penyakit penyerta } & Diabetes melitus & $13,14 \pm 5,53$ & $0,353^{b}$ \\
\hline & Hiperlipidemia & $16,2 \pm 3,81$ & \\
\hline & DM + Hiperlipidemia & $20 \pm 4$ & \\
\hline
\end{tabular}

Keterangan $: \mathrm{a}=$ analisis dengan Mann Whitney; banalisis dengan Kruskal Walis Test

terdapat peningkatan signifikan dalam pengontrolan tekanan darah, hal ini terjadi karena MTM memiliki pendekatan yang berbeda dengan model pelayanan kefarmasian yang lama ${ }^{14}$. Model MTM mengajak semua tenaga kesehatan untuk berkolaborasi dengan pendekatan yang lebih mudah diterima pasien. Mengedepankan peningkatan pengetahuan pasien terhadap penyakit yang dialami, obat yang diminum, hal apa saja yang harus dilakukan, dan dihindari untuk tercapainya tujuan terapi yang optimal. Pada penelitian tersebut disebutkan, persentase awal hanya 55\% pasien yang dapat mencapai goal tekanan darah ideal berubah menjadi $70 \%$ pasien². Terkontrolnya tekanan darah pasien berhubungan dengan meningkatnya kualitas hidup pasien sehingga dapat memperkecil biaya yang dikeluarkan oleh pasien ${ }^{1}$. Salah satu faktor tekanan darah yang belum memenuhi target dapat disebabkan karena waktu pemberian intervensi yang masih sangat terbatas, minimal intervensi dilakukan selama 3 bulan agar perbaikan outcome yang memenuhi target pada pasien hipertensi ${ }^{12}$. Pada pasien Hipertensi disertai dengan DM waktu yang dibutuhkan cenderung lebih lama yaitu 2-3 kali lipat dari pada pasien dengan hipertensi untuk memenuhi target terapi ${ }^{24}$. Perburukan dan perbaikan kualitas hidup ditunjang oleh banyak faktor. Berikut merupakan variabel yang data mempengaruhi kualitas hidup, disajikan dalam tabel VI.

Pada tabel VI, diketahui bahwa dari ke 6 karakteristik tidak ada data variabel yang berpengaruh terhadap outcome pasien hipertensi. Nilai P dari ke-6 karakter variabel di atas $P>0,05$. Yang dirasa paling mendekati dan sedikit memiliki pengaruh adah jenis 
kelamin dengan $\mathrm{P} 0,051$. pendidikan dengan $\mathrm{P}$ 0,741 menandakan pendidikan tidak mempengaruhi tekanan darah sistolik pada pasien. Pada karakteristik Pekerjaan dengan $\mathrm{P}$ 0,106 menandakan pekerjaan tidak mempengaruhi tekanan darah sistol pada pasien. Durasi pasien terkena hipertensi dengan P 0,165 menandakan bahwa lama terjangkit hipertensi tidak mempengaruhi tekanan darah sistol pada pasien. Penyakit penyerta dengan $\mathrm{P}$ 0,353 menandakan penyakit penyerta tidak mempengaruhi tekanan darah sistol pada pasien. Hipertensi merupakan penyakit dengan terapi jangka panjang dan monitoring tindak lanjut. Intervensi apoteker dan kolaborasi seluruh tenaga Kesehatan dirasa penting dan efektif mempertahankan dan meningkatkan outcome klinis serta kualitas hidup pasien hipertensi. Dapat disimpulkan bahwa tidak ada karakteristik yang memiliki pengaruh terdapat perbaikan outcome klinis setelah dilakukannya intervensi pelayanan farmasi berbasis medication therapy management (MTM). Sehingga, adanya perbaikan outcome klinis murni akibat dari intervensi pelayanan farmasi berbasis medication therapy management (MTM).

\section{Keterbatasan Penelitian}

Keterbatasan pada penelitian ini didasarkan dari ukuran sampel yang terbatas sehubungan adanya pandemi COVID-19. Selain itu rentang waktu untuk melihat intervensi dirasa belum sepenuhnya optimal karena hanya dilakukan selama 30 hari setelah dilakukan intervensi sehingga kemungkinan efektivitas peningkatan kualitas hidup dan Outcome klinis berbasis Medication Therapy Management (MTM) masih perlu dilakukan lebih lanjut. Terbatasnya apoteker untuk melakukan intervensi MTM di puskesmas tidak sebanding dengan jumlah pasien yang datang.

\section{KESIMPULAN}

Medication Therapy Management (MTM) memiliki pengaruh yang bermakna terhadap meningkatnya kualitas hidup dan outcome klinis pasien hipertensi $(p<0,001)$. Dapat dilihat semakin tinggi kualitas hidup pasien maka tekanan darah menjadi semakin terkontrol. MTM berperan penting dalam membantu pasien mendapatkan edukasi, konseling sehingga pengetahuan pasien mengenai penyakit dan obat yang diterima dapat bertambah. Semakin mereka paham mengenai penyakit dan obat yang diterima, maka kesalahpahaman pemahaman tentang penyakit mereka akan mengecil, dapat memilih pola makan dan pola hidup yang baik untuk meningkatkan kualitas hidup dan mencapai target goal terapi pasien hipertensi. Dari penelitian ini disimpulkan bahwa MTM dapat menyebabkan perubahan keyakinan dalam pengobatan, perubahan dalam pola hidup, tingkat kepatuhan dan pengetahuan dapat meningkat sehingga akan memperbaiki kualitas hidup pasien menjadi lebih baik dan outcome klinis dapat tercapai.

\section{DAFTAR PUSTAKA}

1. Bolívar JJ. Essential Hypertension: An Approach to Its Etiology and Neurogenic Pathophysiology. Int $J$ ofHypertension. Published online 2013.

2. Al-tameemi NK, Sarriff A. Knowledge, attitude and practice of pharmacists on medication therapy management: a survey in Hospital Pulau. J Pharm Heal Care Sci. 2019;5(1):1-9.

3. APA, Foundation NA of CDS. Medication therapy management in pharmacy practice: Core elements of an MTM service model (version 2.0). J Amarican Pharm Assoc. 2008;48(3):341353.

4. Viswanathan M, Kahwati LC, Golin CE, et al. Medication Therapy Management Interventions in Outpatient Settings A Systematic Review and Meta-analysis. 2015;175(1):76-87.

5. Perlroth D, Packard M, Olinger L. Medication Therapy Management in Chronically Ill Populations: Final Report.; 2013.

6. October E, Table C, Centers $\mathrm{T}$, et al. Program Rujuk Balik Bagi Peserta JKN. 
Departemen Kesehatan Republik Indonesia. 2012;1(1):1-75.

7. Dipiro JT, Talber RL, Yee GC, Matzke GR, Wells BG, Posey LM. 8th Edition Pharmacotherapy A Pathophysiologic Approach.; 2015.

8. World Health Organization. A global brief on Hyper - tension World Health Day 2013. In: ; 2013.

9. Anonim. Riset Kesehatan Dasar 2013. In: Kementerian Kesehatan Republik Indonesia. ; 2013.

10. Anonim. Riset Kesehatan Dasar 2018. In: Kementerian Kesehatan Republik Indonesia. ; 2018.

11. Flanagan S, Damery S, Combes G. The effectiveness of integrated care interventions in improving patient quality of life (QoL) for patients with chronic conditions. An overview of the systematic review evidence. Health Qual Life Outcomes. 2017;15(1):1-11.

12. Ha NT, Duy HT, Le NH, Khanal V, Moorin R. Quality of life among people living with hypertension in a rural Vietnam community. BMC Public Health. 2014;14(1):1-9.

13. Han SJ, Kim HK, Storfjell J, Kim MJ. Clinical outcomes and quality of life of home health care patients. Asian Nurs Res (Korean Soc Nurs Sci). 2013;7(2):5360.

14. Wittayanukorn S, Westrick SC, Hansen RA, et al. Evaluation of medication therapy management services for patients with cardiovascular disease in a self-insured employer health plan. J Manag Care Pharm. 2013;19(5):385-395.

15. Billor N, Braxton-lloyd K, Fox BI, Garza KB. Evaluation of Medication Therapy Management Services for Patients with Cardiovascular Disease in a SelfInsured Employer Health Plan. J Manag Care Pharm. 2013;19(5).

16. Rachmawati Y, Perwitasari DA, Adnan. Validasi Kuesioner Sf-36 Versi Indonesia Terhadap Pasien Hipertensi Di Puskesmas Yogyakarta. Pharmacy. 2014;11(01):14-25.
17. Chua R, Keogh AM, Byth K, Loughlin AO. Comparison and validation of three measures of quality of life in patients with pulmonary hypertension. Intern Med J. 2006;36:705-710.

18. Dos Santos RL, Da Silva FB, Ribeiro RF, Stefanon I. Sex hormones in the cardiovascular system. Horm Mol Biol Clin Investig. 2014;18(2):89-103.

19. Wu JH, Wang SC, Lin LM. Mobile computing acceptance factors in the healthcare industry: A structural equation model. Int $\mathrm{J}$ Med Inform. 2007;76(1):66-77.

20. Yoon SS, Burt V, Louis T, Carroll MD. Hypertension among adults in the United States, 2009-2010. NCHS Data Brief. 2012;(107):1-8.

21. Yoon SS, Gu Q, Nwankwo T, Wright JD, Hong Y, Burt V. Trends in blood pressure among adults with hypertension United States, 2003 to 2012. Hypertension. 2015 ;65(1):54-61.

22. Chajaee F, Pirzadeh A, Hasanzadeh A, Mostafavi F. Relationship between health literacy and knowledge among patients with hypertension in Isfahan province, Iran. Electron physician. 2018;10(3):6470-6477. doi:10.19082/6470

23. Naser Ghasemi A, Peyman N, Tehrani $\mathrm{H}$, et al. The Relationship of Health Literacy with Hypertension SelfEfficacy and General Self-Efficacy Among Schoolteachers. Mod Care J. 2018;15(4).

24. Ramanath $\mathrm{K}$ V., Balaji DBSS, Nagakishore CH, Mahesh Kumar S, Bhanuprakash M. A study on impact of clinical pharmacist interventions on medication adherence and quality of life in rural hypertensive patients. J Young Pharm. 2012;4(2):95-100.

25. De Boer IH, Bangalore $S$, Benetos A, et al. Diabetes and hypertension: A position statement by the American diabetes association. Diabetes Care. 2017;40(9):1273-1284.

26. Lastra G, Syed S, Kurukulasuriya LR, Manrique C, Sowers JR. Type 2 diabetes 
mellitus and hypertension: An update. Endocrinol Metab Clin North Am. 2014;43(1):103-122.

27. Ference BA, Ginsberg HN, Graham I, et al. Low-density lipoproteins cause atherosclerotic cardiovascular disease. 1. Evidence from genetic, epidemiologic, and clinical studies. A consensus statement fromthe European Atherosclerosis Society Consensus Panel. Eur Heart J. 2017;38(32):24592472.

28. Xiao M, Zhang F, Xiao N, Bu X, Tang X, Long $Q$. Health-related quality of life of hypertension patients: A population- based cross-sectional study in Chongqing, China. Int J Environ Res Public Health. 2019;16(13).

29. Kaliyaperumal S, Hari SB, Siddela PK, Yadala S. Assessment of quality of life in hypertensive patients. J Appl Pharm Sci. 2016;6(5):143-147.

30. Dennison-himmelfarb C, Handler J, Lackland DT. 2014 Evidence-Based Guideline for the Management of High Blood Pressure in Adults Report From the Panel Members Appointed to the Eighth Joint National Committee (JNC 8). J Am Med Assoc. 2014;1097:1-14. 